\title{
ANALISIS LIFE STYLE BERDASARKAN FAKTOR KARAKTERISTIK PENDERITA HIPERTENSI DI RW. 09 DESA SRUNI GEDANGAN SIDOARJO JAWA TIMUR INDONESIA
}

\author{
Umdatus Soleha \\ Universitas Nahdlatul Ulama Surabaya, J1. Jemursari 51-57 Surabaya \\ umdatus@unusa.ac
}

\begin{abstract}
Abstrak
Life style dapat membantu pengendalian tekanan darah bagi penderita hipertensi, namun untuk memiliki lifestyle yang sehat bukanlah hal yang mudah bagi kebanyakan orang. Life style yang sehat merupakan salah satu modal dalam penatalaksanaan hipertensi secara non farmakologis. Modernisasi cenderung menjadi hambatan yang besar dalam memiliki life style yang sehat. Tujuan penelitian ini untuk menganalisis life style berdasarkan faktor karakteristik penderita hipertensi di RW.09 Desa Sruni Gedangan Sidoarjo. Desain penelitian deskriptif cross sectional. Populasi dalam penelitian ini adalah penderita hipertensi sebesar 143 orang, besar sampel 105 orang yang diambil melalui teknik simple random sampling. Variabel penelitian adalah life style, usia dan jenis kelamin. Instrumen penelitian ini menggunakan kuesioner, analisis data dilakukan dengan menggunakan analisis deskriptif. Hasil penelitian menunjukkan bahwa dari 105 responden sebagian besar responden adalah perempuan yaitu $53.3 \%$, usia responden hampir setengahnya berada pada rentang usia 56-65 yaitu sebesar $43.8 \%$, life style penderita sebagian besar memiliki life style yang tidak sehat yaitu 63.8\%. Life style yang sehat merupakan faktor penting dalam membantu pengendalian tekanan darah. Pada penderita wanita dan lakilaki sebaiknya sama-sama memiliki upaya yang baik dalam meningkatkan kualitas life style. Penderita hipertensi di RW.02 Desa Sruni Gedangan Sidoarjo, penting dalam melakukan pengendalian tekanan darah melalui pengobatan dan memiliki life style yang sehat. Mengatur life style dengan tidak mengkonsumsi makanan siap saji, beraktifitas dengan teratur, menjaga berat badan tetap ideal, olah raga teratur, tidak merokok dan memiliki mekanisme penanganan stress yang baik sangat disarankan bagi penderita.
\end{abstract}

Kata kunci: life style, usia, jenis kelamin, hipertensi

\begin{abstract}
Life style can help control blood pressure for people with hypertension, but to have a healthy lifestyle is not an easy thing for most people. A healthy life style is one of the capital in the management of nonpharmacological hypertension. Modernization tends to be a big obstacle in having a healthy life style. The purpose of this study was to analyze life style based on the characteristics of hypertensive patients at RW.09 Sruni Village, Gedangan, Sidoarjo. This study was using descriptive cross sectional research design. The population in this study were hypertensive patients with 143 people, a sample of 105 people taken through simple random sampling technique. The research variables are life style, age and gender. The instrument of this study used a questionnaire, data analysis was carried out using descriptive analysis. The results showed that of the 105 respondents most of the respondents were women, namely 53.3\%, the age of respondents almost half were in the age range of 56-65 which was $43.8 \%$, the life style of the sufferers mostly had an unhealthy life style of $63.8 \%$. A healthy life style is an important factor in helping control blood pressure. For women and men, they should both have good efforts in improving the quality of life style. Hypertension sufferers in RW.02 Sruni Village, Gedangan Sidoarjo, are important in controlling blood pressure through medication and having a healthy life style. Regulating life style by not consuming fast food, regular activities, maintaining ideal body weight, regular exercise, not smoking and having a good stress handling mechanism are highly recommended for sufferers.
\end{abstract}

Keywords: life style, age, gender, hypertension 


\section{PENDAHULUAN}

Penyakit hipertensi merupakan penyakit yang dapat menyerang siapapun, seiring bertambahnya usia maka akan semakin meningkat. Hipertensi sebagian besar tidak diketahui penyebabnya, terkadang seseorang tidak mengetahui kalau dirinya menderita hipertensi. Ketika dilakukan pemeriksaan tekanan darah, tiba-tiba didapatkan hasil yang tinggi diatas tekanan darah normal. "Rarely causes symptoms in the early stages and many people go undiagnosed. Those who are diagnosed may not have access to treatment and may not be able to successfully control their illness over the long term" (World Health Organization, 2013).

Modernisasi dan globalisasi berdampak pada life style masyarakat Indonesia, dimana life style merupakan salah satu hal penting yang mempengaruhi terjadinya hipertensi. Life style yang tidak baik atau tidak sehat menjadi pemicu meningkatnya tekanan darah. Penanganan hipertensi meliputi farmakologis dan non farmakologis. Penanganan farmakologis adalah penanganan melalui pemberian obat-obatan oleh dokter, sedangkan penanganan non farmakologis adalah penanganan melalui pengaturan diit, olah raga, penanganan stress, tidak merokok dan tidak mengkonsumsi alkohol. Penderita hipertensi sebaiknya memiliki life style yang sehat, namun kenyataannya banyak penderita yang memiliki life style yang tidak sehat. Penanganan farmakologis, ketika penderita hipertensi mendapatkan obat-obatan dari dokter. Ketika seorang penderita hipertensi rajin untuk minum obat tanpa diimbangi dengan life style yang sehat, maka pengendalian tekanan darah menjadi kurang optimal. Penderita hipertensi selain terapi minum obat, penderita dituntut juga untuk mampu menjalani terapi non farmakologis dengan berperilaku atau memiliki life style yang sehat. Fenomena yang terjadi di masyarakat saat ini menggambarkan life style yang kurang sehat, hal ini terlihat seperti memilih makanan yang instan, kurang olahraga, merokok, minum alkohol, manajemen stress yang tidak baik. Since we live in an affluent society, sed-entary lifestyle has become a feature of our population. In order to deal with the issue of controlling hypertension as a risk factor for CVD, one must study the factors that play a role in regulating the blood pressure. (Alsairafi, Alshamali and Al-rashed, 2010). "Material the numbers of people affected and the prevalence of high blood pressure worldwide are expected to increase over 
the next decade"(Poulter, Prabhakaran and Caulfield, 2015). Menurut data WHO 2015 menunjukkan sekitar 1.13 milliar orang di dunia menderita hipertensi, jumlah penderita hipertensi terus meningkat setiap tahunnya dan diperkirakan pada tahun 2025 akan ada 1.5 miliar orang yang terkena hipertensi (Kemenkes RI, 2018). Di Indonesia berdasarkan data Riskesdas 2018, prevalensi hipertensi sebesar $34.1 \%$ meningkat jauh dibandingkan dengan data sebelumnya yaitu 25.8\%. Pada tahun 2016 didapatkan peningkatan prevalensi hipertensi pada penduduk usia 18 tahun ke atas sebesar 32.4\% (Kemenkes RI, 2018).

Penyakit hipertensi dapat disebabkan oleh beberapa faktor yaitu faktor usia, life style, etnik, jenis kelamin, obat-obatan dan stress (Potter dan Perry, 2010).Pada umumnya masyarakat kurang memperdulikan penyakit hipertensi, karena gejala dan keluhan yang dianggap tidak signifikan. Komplikasi hipertensi akan timbul sebagai akibat tidak terkontrolnya tekanan darah penderita. Komplikasi bisa terjadi pada berbagai organ tubuh, seperti jantung, ginjal, dan otak, dimana timbulnya berbagai penyakit tersebut dapat memperburuk kondisi kesehatan penderita hipertensi. Seiring meningkatnya usia, penyakit hipertensi dapat muncul akibat beberapa perubahan fisiologis yang terjadi. Peningkatan tahanan perifer dan aktifitas simpatis menyebabkan meningkatnya tekanan darah seseorang. Oleh karena itu penderita hipertensi harus mampu melakukan pengendalian tekanan darah melalui life style yang sehat. Tujuan penelitian ini untuk menganalisis life style berdasarkan faktor karakteristik penderita hipertensi di RW.09 Desa Sruni Gedangan Sidoarjo.

\section{METODE PENELITIAN}

Penelitian ini merupakan penelitian deskriptif dengan rancangan cross sectional. Populasi adalah seluruh penderita hipertensi di RW.02 Desa Sruni Gedangan Sidoarjo Jawa Timur, Indonesia sebesar 143 orang. Sampel yang digunakan dalam penelitian ini adalah penderita hipertensi, sebesar 105 responden, pengambilan sampel dilakukan secara Probability sampling dengan teknik simple random sampling. Instrumen yang digunakan dalam penelitian adalah kuesioner yang sudah dilakukan uji validitas dan reliabilitas. Waktu Penelitian dilaksanakan pada periode bulan Maret s.d 
September 2018. Data dianalisis melalui analisis deskriptif.

\section{HASIL DAN PEMBAHASAN}

Berdasarkan hasil penelitian yang diambil melalui data primer pada penderita hipertensi di RW.02 Desa Sruni Gedangan Sidoarjo Jawa Timur didapatkan hasil pada tabel dibawah.

Deskripsi karakteristik penderita hipertensi berdasarkan usia

Tabel.1 Distribusi Frekuensi Responden Berdasarkan Usia

\begin{tabular}{|c|c|c|c|}
\hline No & $\begin{array}{c}\text { Usia } \\
\text { (tahun) }\end{array}$ & Frekuensi & Persentase (\%) \\
\hline 1. & $36-45$ & 14 & 13.3 \\
\hline 2. & $46-55$ & 36 & 34.3 \\
\hline 3. & $56-65$ & 46 & 43.8 \\
\hline \multirow[t]{2}{*}{4.} & $>65$ & 9 & 8.6 \\
\hline & Total & 105 & 100.0 \\
\hline
\end{tabular}

Berdasarkan tabel 1 menunjukkan bahwa dari 105 responden hampir setengahnya berusia 56-65 tahun. Seiring meningkatnya usia, maka tekanan darah seseorang cenderung meningkat dan akan mempengaruhi perubahan fisiologis peningkatan resistensi perifer dan aktifitas simpatis. Disamping hal tersebut sensitivitas baroreseptor terjadi penurunan, fungsi ginjal juga mengalami penurunan dalam bekerja sebagai filtrasi. "Findings from this study are of public health significance as hypertension is one of the most important preventable causes of premature deaths worldwide. Results from this study highlight the importance of adopting an overall healthy lifestyle, particularly in middle aged men who were identified as a higher risk group. The reduction of lifestyle risk factors is anessential component of prevention strategies aimed at reducing the incidence of hypertension and preventing subsequent cardiovascular disease"(Nguyen, Bauman and Ding, 2018).

Deskripsi karakteristik penderita hipertensi berdasarkan jenis kelamin

Tabel. 2 Distribusi Frekuensi Responden Berdasarkan Jenis Kelamin

\begin{tabular}{cccc}
\hline No & Jenis Kelamin & Frekuensi & Persentase (\%) \\
\hline 1. & Laki-Laki & 49 & 46.7 \\
2. & Perempuan & 56 & 53.3 \\
\hline & Total & 105 & 100.0 \\
\hline
\end{tabular}

Berdasarkan tabel 2 menunjukkan bahwa sebagian besar responden $53.3 \%$ berjenis kelamin perempuan. Pada perempuan resiko untuk terjadinya hipertensi akan meningkat setelah menopause yang disebabkan karena menurunnya hormon esterogen, dimana hormone esterogen dapat melindungi kualitas pembuluh darah. "Gender differences were more apparent when lifestyle factors were examined in combination with the pattern of association 
significantly differing between men and women. A higher-risk lifestyle appeared more detrimental for developing hypertension in men than in women"(Nguyen, Bauman and Ding, 2018).Jenis kelamin juga dapat mempengaruhi hipertensi, pada usia sekitar 45 tahun penyakit hipertensi sering dialami oleh pria. Wanita diketahui lebih beresiko menderita hipertensi diatas usia 65 tahun, dimana menopause berkaitan dengan peningkatan resiko hipertensi pada wanita. (Lany Gunawan, 2009).

\section{Life style}

Life style penderita hipertensi di RW.02 Desa Sruni Gedangan Sidoarjo Jawa Timur ditampilkan dalam tabel di bawah ini.

Tabel 3 Distribusi Frekuensi Responden Berdasarkan Life Style

\begin{tabular}{cccc}
\hline No & Life style & Frekuensi & Persentase $(\%)$ \\
\hline 1. & Sehat & 38 & 36.2 \\
2. & Tidak Sehat & 67 & 63.8 \\
\hline & Total & 105 & 100.0 \\
\hline
\end{tabular}

Berdasarkan tabel 3 di atas, 63.8\% penderita hipertensi memiliki memiliki life style tidak sehat. Gambaran life style tidak sehat pada penderita hipertensi di RW.02 Desa Sruni Gedangan Sidoarjo Jawa Timur Indonesia, penderita hipertensi memiliki pola makan lebih suka mengkonsumsi makanan siap saji, menyukai makanan tinggi natrium, kurang menyukai sayur dan buah, penanganan stress yang tidak baik, aktifitas olah raga yang tidak teratur serta kurangnya upaya untuk mempertahankan berat badan secara ideal.

\section{Tabulasi Silang Usia denganLife Style}

Tabel. 4 Tabulasi Silang Usia dengan Life Style

\begin{tabular}{lcccc}
\hline No & Usia & \multicolumn{2}{c}{ Life Style } & $\begin{array}{c}\text { Total } \\
\mathrm{n}(\%)\end{array}$ \\
\hline & & Sehat & $\begin{array}{c}\text { Tidak } \\
\text { Sehat }\end{array}$ & \\
1 & $36-45$ & 6 & 8 & 14 \\
& & $(42.9 \%)$ & $(57.1 \%)$ & $(13.3 \%)$ \\
2 & $46-55$ & 14 & 22 & 36 \\
& & $(38.9 \%)$ & $(61 \%)$ & $(34.3 \%)$ \\
3 & $56-65$ & 13 & 33 & 46 \\
& & $(28.3 \%)$ & $(71.7 \%)$ & $(43.8 \%)$ \\
4 & $>65$ & 5 & 4 & 9 \\
& & $(55.6 \%)$ & $(44.4 \%)$ & $(8.6 \%)$ \\
Total & & 38 & 67 & 105 \\
& & $(36.2 \%)$ & $(63.8 \%)$ & $(100 \%)$ \\
\hline
\end{tabular}

Berdasarkan tabel 4 penderita yang berusia antara 36-45 57.1\% memiliki life style yang tidak sehat. Penderita yang berusia 46-55 sebanyak $61 \%$ memiliki life style yang tidak sehat. Penderita yang berusia 56-65 sebanyak $71.7 \%$ memiliki life style yang tidak sehat dan penderita yang berusia $>65$ tahun sebanyak $55.6 \%$ memiliki life style yang sehat.

\section{Tabulasi Silang Jenis Kelamin dengan Life Style}

Table. 5 Tabulasi Silang Jenis Kelamin dengan Life Style 


\begin{tabular}{ccccc}
\hline No & $\begin{array}{c}\text { Jenis } \\
\text { Kelamin }\end{array}$ & \multicolumn{2}{c}{ Life Style } & $\begin{array}{c}\text { Total } \\
\mathrm{n}(\%)\end{array}$ \\
\hline & & Sehat & $\begin{array}{c}\text { Tidak } \\
\text { Sehat }\end{array}$ \\
1 & Laki-laki & 16 & 33 & 49 \\
& & $(32.7 \%)$ & $(67.3 \%)$ & $(46.7 \%)$ \\
2 & Perempuan & 22 & 34 & 56 \\
& & $(39.3 \%)$ & $(60.7 \%)$ & $(53.3 \%)$ \\
Total & & 38 & 67 & 105 \\
& & $(36.2 \%)$ & $(63.8 \%)$ & $(100 \%)$ \\
\hline
\end{tabular}

Berdasarkan tabel 5 penderita berjenis kelamin laki-laki sebagian besar memiliki life style yang tidak sehat yaitu sebesar $67.3 \%$, demikian juga pada penderita yang berjenis kelamin perempuan sebagian besar memiliki life style yang tidak sehat yaitu sebesar $60.7 \%$.

\section{PEMBAHASAN}

Life Style berdasarkan usia dan jenis kelamin

Hasil studi menunjukkan, Penderita yang berusia antara 36-45 sebesar $57.1 \%$ memiliki life style yang tidak sehat. Penderita yang berusia 46-55 sebanyak $61 \%$ memiliki life style yang tidak sehat. Penderita yang berusia 56-65 sebanyak $71.7 \%$ memiliki life style yang tidak sehat dan penderita yang berusia >65 tahun sebanyak $55.6 \%$ memiliki life style yang sehat. Jumlah atau persentase terbesar untuk life style sehat hanya dimiliki oleh kelompok usia >65 tahun. Hal ini menunjukkan pada usia manula, penderita hipertensi di RW di RW.02 Desa Sruni Gedangan Sidoarjo Jawa Timur Indonesia memiliki life style yang sehat.

Berdasarkan tabel 5 penderita berjenis kelamin laki-laki sebagian besar memiliki life style yang tidak sehat yaitu sebesar $67.3 \%$, penderita yang berjenis kelamin perempuan sebagian besar memiliki life style yang tidak sehat yaitu sebesar $60.7 \%$. Subjek penelitian lebih banyak terjadi pada perempuan, yaitu lebih dari setengah responden adalah perempuan. Wanita lebih cenderung memiliki tekanan darah yang lebih tinggi dari pada laki-laki. Hal ini dikarenakan pada wanita mengalami penurunan kadar hormone esterogen. Prevalensi terjadinya hipertensi pada pria sama dengan pada wanita, namun pada wanita yang belum menopause dilindungi oleh hormon esterogen. Tekanan darah dikendalikan dengan tetap menjaga pola asupan makan, rajin berolahraga dan melakukan pemeriksaan rutin tekanan darah. (lany Gunawan, 2009). Usia dan jenis kelamin dapat mempengaruhi hipertensi, semakin bertambahnya usia maka tekanan darahpun akan semakin meningkat. (Shimbo, 2016). 
Hasil penelitian menunjukkan bahwa sebagian besar penderita hipertensi memiliki life style yang tidak sehat, antara lain menunjukkan perilaku suka mengkonsumsi makanan siap saji, mengkonsumsi makanan asin atau tinggi natrium, tidak mengatur diit untuk mempertahankan BB ideal, makan makanan yang diawetkan dan memiliki kebiasaan merokok. Menurut Iskandar Junaedi (2010) hipertensi sering menyebabkan perubahan pembuluh darah, yang mengakibatkan makin tingginya tekanan darah. Oleh sebab itu penanganan dini pada hipertensi sangatlah penting, karena dapat mencegah timbulnya komplikasi pada beberapa organ tubuh, seperti jantung, ginjal, dan otak. Penanganan sejak dini untuk mencegah komplikasi dapat melalui pengaturan pola makan. Sebagaimana telah diketahui mengenai penatalaksanaan hipertensi selain farmakologis juga tidak kalah pentingnya penanganan non farmakologis. Life style banyak duduk dan kurang aktivitas fisik meningkatkan resiko munculnya penyakit kronik modern, kurang gerak dan mengkonsumsi tinggi lemak memudahkan terjadinya obesitas, yang menjadi pemicu hipertensi. Pada umumnya obesitas sangat dekat dengan peningkatan kadar gula, lemak darah, hipertensi dan diabetes mellitus (Cahyono, 2008).

Memiliki life style yang sehat tidak merokok, menghindari alkohol, tidur yang cukup, menurunkan berat badan berlebih, mengatur pola makan dan berolahraga yang teratur dapat membantu membakar lemak dan kalori yang berlebih (Tandra, 2014). Life style tidak sehat akan memperburuk kondisi penderita hipertensi, menyebabkan resiko munculnya komplikasi pada beberapa target organ.

Sebagai Negara yang berkembang, Indonesia telah banyak mengalami pergeseran sisi kehidupan sosial, perubahan dalam life style. Banyaknya bermunculan restoran siap saji, menyebabkan masyarakat memiliki kecenderungan untuk mengkonsumsi makanan siap saji yang tinggi natrium. Kemudahan untuk membeli makanan siap saji melalui aplikasi online, mendorong masyarakat untuk bergaya hidup tidak sehat, menurunnya motivasi untuk memasak sendiri, merubah paradigm berpikir.

Jaman dahulu masyarakat lebih termotivasi untuk memasak dan mengolah makanan sendiri, menanam buah dan sayur di depan rumah untuk dimanfaatkan sendiri, namun saat ini semua itu susah didapatkan. 
Masyarakat cenderung memilih cara yang simple, mudah dan membutuhkan cost yang tidak jauh berbeda dibandingkan ketika harus memasak sendiri dan membutuhkan tenaga ekstra untuk mengolah makanan. Fenomena ini juga telah terjadi pada masyarakat di Desa Sruni Sidoarjo Jawa Timur Indonesia, dimana di desa ini sudah banyak restaurant siap saji dan masyarakat sudah familier dalam memenuhi kebutuhannya melalui layanan online yang serba memudahkan.

Faktor yang mempengaruhi terjadinya hipertensi yaitu genetik, umur, jenis kelamin, dan etnis. Selain itu ada faktor pemicu yang menyebabkan terjadinya hipertensi berasal dari lingkungan yaitu life style seperti merokok, alkohol, asupan garam berlebih, kurang olahraga, dan stres. (Cahyono, 2008).

Menurut Iskandar Junaedi (2010) hipertensi sering menyebabkan perubahan pembuluh darah, yang mengakibatkan makin tingginya tekanan darah. Oleh sebab itu penanganan secara dini pada hipertensi sangatlah penting, karena dapat mencegah timbulnya komplikasi pada beberapa organ tubuh, seperti jantung, ginjal, dan otak. Pengendalian berat badan, pengurangan asupan natrium, aktifitas secara teratur, pengurangan kalori, mengurangi asupan alcohol, pengendalian stress dapat mengendalikan tekanan darah. Selain itu ada faktor pemicu yang menyebabkan terjadinya hipertensi berasal dari lingkungan yaitu life style seperti merokok, alkohol, asupan garam berlebih, kurang olahraga, dan stres. (Cahyono, 2008). Salah satu cara mengendalikan tekanan darah dengan modifikasi life style seperti diet rendah garam, memeriksakan tekanan darah secara teratur, diet rendah lemak, mengatur pola makan, menurunkan berat badan, olahraga, berhenti merokok, berhenti mengkonsumsi alkohol, dan tidak stres berlebihan (Cahyono, 2008). Hal ini harus dilakukan oleh penderita hipertensi baik laki-laki maupun perempuan dan pada semua tingkatan usia.

\section{SIMPULAN DAN SARAN}

Pada penelitian ini faktor karakteristik yang meliputi jenis kelamin dan usia merupakan salah satu faktor yang mempengaruhi life style terutama pada pasien hipertensi.

Life style yang sehat merupakan faktor penting dalam membantu pengendalian tekanan darah. Pada penderita wanita dan laki-laki sebaiknya sama-sama memiliki upaya yang baik dalam meningkatkan kualitas life style. Penderita hipertensi di 
RW.02 Desa Sruni Gedangan Sidoarjo, penting dalam melakukan pengendalian tekanan darah melalui pengobatan dan memiliki life style yang sehat. Mengatur life style dengan tidak mengkonsumsi makanan siap saji, beraktifitas dengan teratur, menjaga berat badan tetap ideal, olah raga teratur, tidak merokok dan mamiliki mekanisme penanganan stress yang baik.

\section{REFERENSI}

Alsairafi, M., Alshamali, K. and Al-rashed, A. (2010) 'Effect of Physical Activity on Controlling Blood Pressure among Hypertensive Patients from the Mishref Area of Kuwait.', European Journal of General Medicine, 7 (4), pp. 377-384. Available at: http://search.ebscohost.com/login.aspx? direct=true $\& d b=r z h \& A N=104318104 \&$ site=ehost-live.

Baradero Mary. (2010). Client Cardiovascular Disorders. Jakarta, EGC

Cahyono, S. B, 2008, Gaya Hidup dan penyakit modern, Yogyakarta, Kanisius

Gunawan Lany. (2009).Hypertension High Blood Pressure. Yogyakarta, Kanisius (Member of IKAPI).

Junaidi, Iskandar (2010). Hypertension. Jakarta. BIP Gramedia Group.

Ministry of Health.(2018).http://www.depkes.go.id/a rticle/view/18051600004/ hypertensionkill-secretly-know-your-blood pressure.html, access 29 October, 2018.

Kurniadi Helmanu., Nurrahmani Ulfa. (2016). Stop Diabetes Hypertension High Cholesterol Heart Rate. Jakarta. Media Palace.

Martha, Karnia. (2012). Smart Guide to Overcoming Hypertension. Yogyakarta. Araska.

Nguyen, B., Bauman, A. and Ding, D. (2018) 'Association between lifestyle risk factors and incident hypertension among middle-aged and older Australians', Preventive Medicine. Elsevier, 118 (September 2018), pp. 7380. doi: 10.1016 / J.YPMED.2018.10.007.

Notoatmodjo, Soekidjo. (2012). Health Research Methodology. Jakarta, Rineka Cipta.

Poulter, NR, Prabhakaran, D. and Caulfield, M. (2015) 'Hypertension', in The Lancet. doi: 10.1016 / S0140-6736 (14) 61468-9.

Shimbo, D. (2016) 'Dietary and lifestyle factors in hypertension', Journal of Human Hypertension. Nature Publishing Group, 30 (10), pp. 571-572. doi: 10.1038 / jhh.2016.57.

Tandra H. Life Healthy with Diabetes Mengapa dan Bagaimana. Yogyakarta: CV. Andi Offset

World Health Organization (2013) A global brief on Hypertension - World Health Day 2013, World Health Organization. doi: 10.1136 / bmj.1.4815.882-a 